Dorota Anna Łażewska*

Józefów k. Otwocka

\title{
Dekonstrukcja logosu jako zagrożenie dla życia religijnego
}

Tytuł prezentowanego tekstu streszcza wszystkie jego podstawowe wątki. Najważniejszy z nich stanowi życie religijne. Do życia religijnego odnosi się przecież i jemu zagraża wspomniana dekonstrukcja logosu. Życie religijne będzie tu rozumiane w kształcie katolickim jako relacja wiary, nadziei i miłości Boga z człowiekiem, „sprawian[a] w nas przez Chrystusa". Więź wiary, nadziei i miłości jest związkiem realnym, ponieważ posiadając realne podstawy w strukturze bytu ludzkiego, odnosi się do realnej osoby $\mathrm{Boga}^{2}$. Wytrwanie $\mathrm{w}$ wierze, nadziei i miłości nie jest łatwe. Wymaga swoistego rodzaju walki, która toczy się z szatanem, światem i ciałem, a teorie strategii i taktyki owej walki stanowią obecnie integralny element katolickiej teologii ascetyczno-mistycznej ${ }^{3}$.

Fakt duchowego zmagania się o zachowanie relacji wiary z Bogiem nie należy jednak do historii teologii. Wiek XXI jest również terenem tej walki. Zagrożeniem dla życia wiary może być bowiem dekonstrukcyjny spo-

* Dr Dorota Anna Łażewska jest adiunktem w Wyższej Szkole Gospodarki Euroregionalnej im. Alcide De Gasperi w Józefowie k. Otwocka. Adres: Wyższa Szkoła Gospodarki Euroregionalnej, ul. Sienkiewicza 4, 05-410 Józefów; e-mail: tales.ratio@wp.pl.

${ }^{1}$ Mieczysław Gogacz, Podstawy wychowania (Niepokalanów: Wydawnictwo oo. Franciszkanów, 1993), 47.

${ }^{2}$ Zofia J. Zdybicka, Człowiek i religia. Zarys filozofii religii (Lublin: Wydawnictwo Towarzystwa Naukowego KUL, 1993), 344-248.

${ }^{3}$ Wawrzyniec Scupoli, Walka duchowa (Poznań: Klub Książki Katolickiej, 2002), 94, $100,102,190$. 
sób myślenia kształtujący (a raczej zniekształcający) współczesną kulturę intelektualną. Celem niniejszej refleksji jest zatem ukazanie istoty tego zagrożenia. Poszczególne etapy tej refleksji, stanowiące wyodrębnione części niniejszego artykułu, mają ukazać wiarę jako naturalny element życia indywidualnego i społecznego oraz, w kontekście wiary naturalnej, wiarę nadprzyrodzoną wraz z jej dążeniem do rozumienia. Kolejne części to uwyraźnienie dekonstrukcji jako strategii myślowej poszukującej niepewności wraz z opisem jej efektów w życiu wiary oraz związanych z tą sytuacją zadań, których realizacja należy do pedagogiki religii.

\section{Wiara naturalna i wiara religijna}

Poprzestańmy obecnie na temacie wiary. Wiara nie powinna być kojarzona wyłącznie z religią. Wiara, jako relacja osobowa, stanowi naturalne środowisko życia człowieka. Spoglądając na człowieka z perspektywy metafizycznej, można bowiem zauważyć, iż jest on realny, dobry i prawdziwy. Z powodu oddziaływania własności realności, prawdy i dobra jednego człowieka na własności realności, prawdy i dobra drugiego człowieka nawiązują się relacje osobowe. Interesująca nas relacja wiary powstaje na skutek wzajemnego oddziaływania własnością prawdy. Dzięki niej przedmiot poznawczy jest jawny i dostępny. Postacią relacji wiary jest zaś prawdomówność i zaufanie. I tu mamy kolejną perspektywę metafizyczna, ponieważ tylko z takiej perspektywy można „zobaczyć”, czyli zidentyfikować, relacje osobowe. Identyfikacja polega bowiem na poszukiwaniu przyczyn właściwych dla skutków, a tym zajmuje się metafizyka. Ukazywanie przyczyn to wskazywanie na powiązania wewnątrzbytowe (pomiędzy aktem i możnością, istotą i istnieniem) oraz powiązania zewnętrzne zachodzące pomiędzy dwoma odrębnymi bytami. Więzi te nazywane są w metafizyce relacjami ${ }^{4}$.

Znaczenie relacji wiary nawiązywanej w życiu codziennym nie jest doceniane pomimo empirycznego faktu, na który zwrócił uwagę Jan Paweł II, pisząc, iż „W życiu człowieka nadal jest o wiele więcej prawd, w które po prostu wierzy, niż tych, które przyjął po osobistej weryfikacji”. I gdybyśmy musieli poddawać „krytycznej ocenie niezliczone wyniki badań naukowych [czy] kontrolować strumień informacji”" , przemierzając drogi doświadczeń

4 Mieczysław Gogacz, Elementarz metafizyki (Warszawa: Oficyna Wydawnicza „Navo”, 2008), 54, 59-66, 123-131.

5 Jan Paweł II, Fides et ratio (Poznań: Pallottinum, 1998), 31. 
poprzednich pokoleń, to egzystencja ludzka byłaby nie do zniesienia. Każdy bowiem zaczynałby wszystko od początku' ${ }^{6}$. Wiara naturalna leży zatem u podstaw życia społecznego. „Kultura zaufania” to jego integralny element. „Kultura nieufności” demotywuje, a w konsekwencji oznacza pasywizm, ostrożność, alienację, anonimowość i atomizację społeczeństwa ${ }^{7}$.

Na podstawie powyższych informacji można wnioskować, że umiejętność zawierzenia to jeden z najbardziej doniosłych aktów świadczących o społecznej naturze człowieka ${ }^{8}$. Niewiara byłaby więc zjawiskiem sprzecznym $\mathrm{z}$ naturą ${ }^{9}$. Antropologiczna struktura wiary jest również obecna $\mathrm{w}$ relacji z Bogiem. I pomimo tego, że nie wszyscy wierzą w Boga, to sam akt wiary jest czymś naturalnym dla wszystkich ${ }^{10}$.

\section{Wiara czyli poszukiwanie pewności}

Wiara (zarówno ta naturalna, jak i religijna) nie przeszkadza w myśleniu. Każdy, kto wierzy, myśli, „myśląc wierzy, wierząc myśli” (św. Augustyn $)^{11}$. Nieodłącznym składnikiem wiary jest zatem wiedza, która w tym przypadku bywa rozumiana jako jej mniej doskonała, tymczasowa (prowizoryczna) forma. Pochodząca z niej pewność ma być zaś gorszą odmianą pewności w porównaniu $\mathrm{z}$ tą, której źródłem jest nasze bezpośrednie (naoczne) doświadczenie ${ }^{12}$. Trzeba tu jednak pamiętać, że dzięki wierze „czyjaś wiedza staje się moją wiedzą". Człowiek ufający ma udział w wiedzy innych osób. Wiara naturalna znajduje więc uzasadnienie „w wiedzy tych, którzy

${ }^{6}$ Joseph Ratzinger, Patrzac na Chrystusa. Ćwiczenia w wierze, nadziei, miłości (Warszawa: Katolicka Agencja Wydawnicza „MAG”, 1991), 11.

${ }^{7}$ Katarzyna Ferszt-Piłat, „Zaufanie jako fundament bezpieczeństwa we współczesnym społeczeństwie", Journal of Modern Science 3 (2012): 112, 117.

8 Jan Paweł II, Fides, 33.

9 Tomasz z Akwinu, za: Joseph Ratzinger, Europa Benedykta w kryzysie kultur (Częstochowa: Edycja św. Pawła, 2005), 123.

${ }^{10}$ Benedykt XVI, „Wiara, rozum i uniwersytet - wspomnienia i refleksje”, L'Osservatore Romano 11 (2006): 25-27.

11 Augustyn, „De praedestinatione sanctorum”, 2, 5, w: Patrologia Latina I-CCXVII (I-IV Indices), red. J. P. Migne (Paris 1878-1890), 44, 963 - za Wojciech Cichosz, Wychowanie chrześcijańskie wobec postmodernistycznej prowokacji (Gdańsk: Zakłady Graficzne im. KEN, 2001), 194.

12 Joseph Ratzinger, Wiara i przyszłość (Kraków: Wydawnictwo Salwator, 2007), 19. 
znają daną dziedzinę lub ją sprawdzili”'13. Wiara odnosi się przecież „zawsze do kogoś, kto «zna się na rzeczy»"14. Prawidłowość ta zachodzi również w przypadku wiary religijnej. I tu wiedza pochodzi z bezpośredniego (naocznego) doświadczenia. W tej sytuacji chodzi o wiedzę zdobytą dzięki osobistemu spotkaniu z Jezusem. I dlatego również wiara chrześcijańska jest udziałem w wiedzy osób znających się na rzeczy ${ }^{15}$.

W refleksji nad treściami religijnymi nie można uniknąć filozoficznego sposobu myślenia. Jeżeli zatem wierzący „próbuje we właściwym tego słowa znaczeniu rozumieć [prawdy wiary], wchodzi w myślenie filozoficzne"16. Dysponujemy przy tym stylami myślenia wielu filozoficznych szkół i kierunków. Wśród nich można wyróżnić fenomenologię, hermeneutykę, egzystencjalizm i pozytywizm. Owe nurty to swoistego rodzaju odmiany języka, od którego wyboru zależy treść i forma wypowiedzi. Na przykład mówiąc po łacinie albo posługując się greką - tą najbardziej „mowną mową” - można wiele wyrazić. Język zbyt ubogi gramatycznie lub leksykalnie już na to nie pozwoli. Zasada ta sprawdza się również w przypadku języków filozoficznych. I tak egzystencjalizm przybliża rozumienie sytuacji granicznych, lęków i nadziei człowieka, fenomenologia opisuje zaś istotę oraz esencję, czyli teorię bytów możliwych. Z kolei metafizyka to narzędzie komunikowania tego, co realne, a nie pomyślane lub wyobrażone w polu własnej lub cudzej świadomości. Jeżeli zatem chcemy mówić o Bogu istniejącym, to adekwatnym językiem filozoficznym będzie język metafizyki realistycznej. Nie jest zatem obojętne, na jakiej filozofii opierają się teologowie i do jakiej filozofii odwołują się ludzie wierzący ${ }^{17}$.

\section{Dekonstrukcja czyli poszukiwanie niepewności}

Jednym ze współczesnych stylów filozoficznego myślenia jest dekonstrukcja $^{18}$, której specyfikę opisał francuski filozof Jacques Derrida ${ }^{19}$. Dekon-

${ }^{13}$ Ratzinger, Europa, 125-128.

${ }_{14}$ Ratzinger, Patrzac, 10.

15 Ratzinger, Europa, 129.

16 Joseph Ratzinger, Prawda w teologii (Kraków: Wydawnictwo M, 2005), 20.

17 Stefan Swieżawski, Dobro i tajemnica (Warszawa: Biblioteka „Więzi,” 1995), 17-19.

18 Wolfgang Welsch, Nasza postmodernistyczna moderna (Warszawa: Oficyna Wydawnicza, 1998), 280.

${ }_{19}$ Do najważniejszych publikacji Jacques'a Derrida można zaliczyć następujące pisma: O gramatologii, Marginesy filozofii, Pozycje, Pismo i różnica, Głos i fenomen. 
strukcyjny sposób myślenia odgrywa dziś znaczącą rolę. Jego wpływ nie jest jednak doceniony. Poszukując przyczyn dynamicznych przekształceń życia społecznego (w tym religijnego), nie wiąże się owych zmian z działaniem dekonstrukcyjnych strategii. Termin ten jest raczej rozumiany jako kategoria należąca do dziedziny „czystej filozofii” lub „zabytek” myśli filozoficznej. Teksty o dekonstrukcji pochodzą przecież z lat 60. XX wieku. Dekonstrukcję traktuje się też jako ,nieszkodliwą grę akademicką"20. Miejscem toczącej się gry dekonstrukcyjnej nie jest jednak akademia, lecz współczesność, w tym życie religijne, czyli przestrzeń, w której nawiązywane są osobowe relacje pomiędzy Bogiem a człowiekiem.

Czym jest dekonstrukcja? Trudno na to pytanie odpowiedzieć, gdyż dekonstrukcja unika odpowiedzi na pytanie o własną tożsamość, naturę, istotę. Nie można zatem dekonstrukcji zdefiniować (pojęciować), zamykając ją w „racjonalnej przestrzeni argumentacyjnej”21.

I tu już stykamy się z tematem dekonstrukcji logosu. Pomimo różnych znaczeń nadawanych temu terminowi oraz jego długiej historii można uznać, iż logos stanowi przeciwieństwo słów pustych ${ }^{22}$. Jest więc „słowem znaczącym”, nie zaś rumowiskiem czy bezładną mieszaniną składników ${ }^{23}$. Człowiek poznając coś chce to coś zarazem zrozumieć czyli uchwycić jego znaczenie, istotę - pierwiastek inteligibilny. Pyta więc o definicję. Wyartykułowanie definicji jest sposobem na rozumienie poznawczego przedmiotu. Definiując wskazujemy bowiem na dwie z czterech przyczyn: materię i formę. Rozumienie jest przecież możliwe dopiero w świetle owych przyczyn ${ }^{24}$. Jednak sam Derrida już na wstępie utrudnia nam zadanie zrozumienia czegoś. Filozof ten bowiem na pytanie: co to jest dekonstrukcja? odpowiada: nie wiem, czy coś takiego istnieje ${ }^{25}$. Natomiast komentatorzy francuskiego

${ }^{20}$ Anna Burzyńska, Dekonstrukcja i interpretacja (Kraków: Towarzystwo Autorów i Wydawców Prac Naukowych Universitas, 2001), 31.

${ }^{21}$ Włodzimierz Zięba, Dekonstrukcja metafizyki. Powstanie (J. Derrida) - Rozkwit-Niespetnienie (R. Rorty) (Rzeszów: Wydawnictwo Uniwersytetu Rzeszowskiego, 2009), 111.

${ }^{22}$ Tomasz Mazur, Kapryśni bogowie Sokratesa. Człowiek $i$ świat wartości w tradycji filozofii zachodniej (Kęty: Wydawnictwo Marek Derewiecki, 2008), 88, 90.

${ }^{23}$ Ewa Borowska, Problem metafizyki. Ewolucja metafizyki europejskiej w interpretacji późnego Heideggera (Warszawa: Wydawnictwo Naukowe Scholar, 2008), 52-53.

${ }^{24}$ Giovanni Reale, Historia filozofi starożytnej. T. I. Od poczatków do Sokratesa (Lublin: Redakcja Wydawnictw KUL, 1994), 472-473.

25 Jacques Derrida, „List do japońskiego przyjaciela”, w: Efekt inskrypcji. Jacques Derrida i literatura, red. Michał P. Markowski (Bydgoszcz: Studio Ф: ’Homini”, 1997), 120-122. 
filozofa wyjaśniają: „dekonstrukcja nie jest tym, co myślisz”26. Trudności w zdefiniowaniu dekonstrukcji świadczą o występowaniu zjawiska burzenia struktur logocentrycznych. Zresztą sam Derrida wyjaśniał, iż burzenie struktur logocentrycznych to właśnie zadanie dekonstrukcyjnych zabiegów ${ }^{27}$. Strategie dekonstrukcyjnego myślenia nie służą zatem do rozwiązywania problemów lub formułowania sensownych odpowiedzi. Nie wykazują też braku sensowności, lecz uwalniają od sensu. „Sens [okazuje] się więc nigdy nie-właściwy, co bynajmniej wcale nie [oznacza]: niewłaściwy" ${ }^{28}$. Chodzi raczej o wydobycie „nierozstrzygalników”, czyli wykazanie, iż rozstrzygnięcie danej kwestii nie jest możliwe. Dekonstrukcja wprowadza więc w doświadczenie aporii, duchowej rozterki, sytuacji bez wyjścia. Uniemożliwia rozumienie. Powoduje, że dany temat zaczyna być niejasny. Innymi słowy dekonstrukcja ,rozwiewa [...] «wiarę w rozum»" 29 .

Sytuację braku rozumienia można lepiej zrozumieć, zestawiając dekonstrukcję z takimi postawami myślowymi jak dogmatyzm i nihilizm. Mianownikiem jest tu pewność co do istnienia lub nieistnienia prawdy. Nihilista jest pewny, że nie ma pewności. Dogmatyk natomiast ma pewność, że pewność istnieje ${ }^{30}$. Postawy te posiadają zatem pewien punkt odniesienia - pierwiastek inteligibilny, którym jest posiadanie pewności, „rozumienie” czegoś. Dekonstrukcja rodzi poczucie niepewności. Dlatego dekonstrukcyjny sposób myślenia przebiega w następujący sposób: prawda „nie została dotąd odkryta i nie jest na pewno nam niedostępna. Nie jest na pewno nam dostępna, ale też nie jest na pewno nam niedostępna" ${ }^{31}$. I tak w przypadku działania dekonstrukcji „nigdy nie jesteśmy w stanie zacisnąć pięści na [jakimkolwiek] znaczeniu"32.

${ }^{26}$ Geoffrey Bennington, „Deconstruction is not what you think”, w: Deconstruction: Omnibus Volume, red. A. Papadakis, C. Cooke, A. Benjamin (London: Academy Editions 1989), 84 - za Burzyńska, Dekonstrukcja, 49.

27 Derrida, „List”, 91-92, 120-122.

28 Burzyńska, Dekonstrukcja, 468.

${ }^{29}$ Hillis Miller za Burzyńska, Dekonstrukcja, 448, 425, 469.

30 Jacek Breczko, „Dwa tysiące sześćsetletni poród. Zmierzch czy świt filozofii?”, Sofia 7 (2007): 346-347; por. Jacek Breczko, „Na wąskiej kładce między dogmatyzmem a agnostycyzmem”, w: Jacek Breczko, Dwa tysiqce sześćsetletni poród. Wstęp do filozofii (Białystok: Wyższa Szkoła Administracji Publicznej im. Stanisława Staszica, 2007), 129.

${ }^{31}$ Breczko, „Dwa tysiące”, 347.

32 Burzyńska, Dekonstrukcja, 470. 


\section{Strategie i efekty poszukiwania niepewności}

Dekonstrukcja wprowadza umysł w stan niepewności przy pomocy specyficznych dla siebie strategii. Wspomniany brak jasności jest przejawem wyrzekania się dominacji ${ }^{33}$, czyli odchodzenia od takiego układu, w którym jeden element znajduje się wyżej od drugiego. Derrida określił owe zestawienia mianem binarnych układów podporządkowania. Wśród nich wyróżnił takie pary przeciwieństw jak: teoria/praktyka, centrum/peryferie, byt/ /nicość, dobro/zło, substancja/przypadłość, natura/kultura, męskie/żeńskie, racjonalne/nieracjonalne. Stanowią one jakby metafizyczną matrycę porządkującą zachodni sposób myślenia ${ }^{34}$. Został on bowiem ukształtowany pod wpływem klasycznej filozofii greckiej, zwłaszcza zaś jej wersji platońskiej. Platon odkrywając świat idei dokonał jednej z najbardziej wpływowych ,rewolucji" w dziejach Europy. Podzielił świat na dwa poziomy: gorszy świat zmysłowy (rzeczywistość konkretnych osób, rzeczy i zjawisk) i lepszy świat ponadzmysłowy (miejsce przebywania idei owych osób, rzeczy i zjawisk). Od czasów Platona można zatem mówić o tym, co jest widzialne/niewidzialne, wyższe/niższe, lepsze/gorsze ${ }^{35}$.

I jeżeli dekonstrukcja kojarzy się z niszczeniem, to tylko w sensie destrukcji owej „dominacji jednego trybu znaczenia nad innym"36. Świat „pomyślany” poza tym konceptuarium jest podobnym do kłącza pluralistycznym światem różnic, będącym acentrycznym systemem, bez początku i końca, w którym odbywa się niekontrolowane „rozsiewanie” i „rozplenianie się" sensów ${ }^{37}$, tworzących mieszaninę ,spierających się ze sobą form”38.

33 Ernest Gellner, Postmodernizm, rozum i religia (Warszawa: Państwowy Instytut Wydawniczy, 1997), 97.

${ }^{34}$ Zięba, Dekonstrukcja, 36-37.

${ }^{35}$ Giovanni Reale, Historia filozofii starożytnej. T. II. Platon i Arystoteles (Lublin: Redakcja Wydawnictw KUL, 1997), 75-78.

${ }^{36}$ Burzyńska, Dekonstrukcja, 423, 28.

37 Bogdan Banasiak, Filozofia ,, końca filozofii”. Dekonstrukcja Jacquesa Derridy (Warszawa: Spacja, 1997), 123-128.

38 Wolfgang Welsch, „Rozum i przejścia. O rozumie transwersalnym”, w: Rozumność i racjonalność, red. Tadeusz Buksiński (Poznań: Wydawnictwo Naukowe Instytutu Filozofii UAM, 1997), 94. 
Oto świat zdekonstruowany czyli postmetafizyczny. Poza strukturą logocentrycznej metafizyki ${ }^{39}$ jest przecież tylko „nagi i nieskrywany pluralizm” ${ }^{40}$.

Jaką rolę w owej nieprzejrzystej sytuacji pełni rozum? Mianowicie, sprzymierzając się z owym nieporządkiem, może wyjaśniać, jak poprawnie poruszać się pośrodku niego, wskazując na sposoby przechodzenia pomiędzy różnymi postaciami współczesnej „racjonalności”. Takiego rozumu nie można nazwać rozumem logocentrycznym, lecz rozumem transwersalnym. I jeżeli za motto stanu postmoderny przyjmuje się wyrażenie farewell to reason, to nie oznacza to rozstania z rozumem samym w sobie, lecz rozumem tradycyjnym, czyli poszukującym przyczyn rzeczywistości ${ }^{41}$. „Rozumowe [bowiem] ma być to, co pozwala porzucić odziedziczone obstawanie przy rozumie"42.

Jakimi argumentami dysponuje strategia dekonstrukcji? Otóż swoistym dekonstrukcyjnym ,argumentem” jest banalizowanie, ironizowanie oraz swobodna zabawa tekstami ${ }^{43}$, możliwościami i skojarzeniami ${ }^{44}$. Dlatego, jak twierdził Jürgen Habermas, dekonstrukcja stanowi ,klasyczny przykład ofiary złożonej z intelektu [...] na ołtarzu błazeńskiej gry"45 i niekończącej się interpretacji. Nie należy przy tym mylić dekonstrukcyjnej ironii z ironią sokratejską. Faktycznie, Sokrates posługiwał się ironią w celu zdemaskowania złudnej wiedzy swych rozmówców. Jednak ironia ta posiadała wartość metodologiczna. Uczestnik dialogu przy pomocy różnych forteli i sztuczek intelektualnych był wciagany w rozmowę, aby poprzez większe zaangażowanie umysłowe samodzielnie sformułował jakieś konstruktywne wnioski ${ }^{46}$. Natomiast dekonstrukcyjna ironia jest pusta ${ }^{47}$.

39 Michael Dummet, Logiczna podstawa metafizyki. Natura i przyszłość filozofii (Warszawa: Państwowe Wydawnictwo Naukowe, 1998).

40 Welsch, Nasza, 260-262, 197, 204.

${ }^{41}$ Odo Marquard, Rozstanie z filozofia pierwszych zasad: studia filozoficzne (Warszawa: Oficyna Wydawnicza, 1994), 3-5.

${ }^{42}$ Welsch, „Rozum”, 91.

${ }^{43}$ Waldemar Furmanek, „Banalizacja urzeczywistniana wartości”, w: Wartości w pedagogice. Urzeczywistnianie wartości, red. Waldemar Furmanek, Agnieszka Długosz (Rzeszów: Wydawnictwo Uniwersytetu Rzeszowskiego, 2015), 174-182; por. Zięba, Dekonstrukcja, 94, 105, 132-143; Burzyńska, Dekonstrukcja, 422-425.

${ }^{44}$ Magdalena Żardecka-Nowak, Wspólnota i ironia. Richard Rorty i jego wizja społeczeństwa liberalnego (Lublin: Wydawnictwo KUL, 2003), 115.

45 Piotr Maksymiuk, „Derridiański taniec”, Preteksty 4 (2007): 107; por. Burzyńska, Dekonstrukcja, 458.

${ }^{46}$ Reale, Historia, t. II, 58-59.

47 Dorota Łażewska, „Derridiańska dekonstrukcja jako strategia odrzucania wartości prawdy w pedagogice”, w: Wartości w pedagogice. Urzeczywistnianie wartości, red. Walde- 
Zamierzonym efektem dekonstrukcji jest „dekonstrukcja ujęć tożsamościowych"48. Jak sugerują socjolodzy, pedagodzy i filozofowie, tożsamość powinna być nieokreślona i tymczasowa, zmienna i przygodna, zależna jedynie od kontekstu. Trzeba zatem przyjąć zmodyfikowaną wersję heraklitejskiej tezy, że „nie można wstąpić dwa razy do tej samej rzeki”"49 i zgodzić się z tym, że „,[n]ie można dwa razy wstąpić do tego samego podmiotu" ${ }^{50}$. Rozmyta zatem zostaje tożsamość rodziny, która przypomina obecnie elastyczną i niestabilną strukturę kłącza. Unifikacji i neutralizacji podlega tożsamość płciowa mężczyzny i kobiety ${ }^{51}$. Tożsamości nie posiada przecież sama strategia dekonstrukcji. „Praca dekonstrukcji polega w swej istocie na poddaniu próbie wytrzymałości każdego elementu, który rości sobie pretensje do [...] logicznych zasad tożsamości, sprzeczności i wyłączonego środka" ${ }^{\prime 52}$.

\section{Efekty niepewności w życiu wiary}

Efektem działania dekonstrukcyjnego sposobu myślenia jest zaburzenie rozumienia tożsamości chrześcijańskiej. Najpierw zaś odrzucenie Boga osobowego (Logosu) - pierwszej zasady rzeczywistości $i^{53}$, fundamentu, centrum, kogoś zawsze obecnego. Burzenie struktur logocentrycznych to przecież pierwszoplanowe zadanie dekonstrukcyjnych zabiegów. Dalsze zjawiska to konsekwencje braku centrum. „Bez podstawy - fundamentu - zasady - centrum nie ma gmachu, nie ma struktury". Pozostaje niepewność, nierozstrzygalny spór i niekończąca się gra ${ }^{54}$.

mar Furmanek, Agnieszka Długosz (Rzeszów: Wydawnictwo Uniwersytetu Rzeszowskiego, 2015), 170-171.

48 Joanna Mizielińska, (De)Konstrukcje kobiecości. Podmiot feminizmu a problem wykluczenia (Gdańsk: Słowo/Obraz/Terytoria, 2004), 8.

49 Reale, Historia, t. I, 94.

50 Jacek Breczko, „Nowożytność jako pole bitewne antropologii”, w: Jacek Breczko, Cywilizacja na zakręcie. Szkice z historii filozofii i z filozofii historii (Lublin: Norbertinum, 2014), 66.

${ }^{51}$ Krystyna Slany, Alternatywne formy życia matżeńsko-rodzinnego w ponowoczesnym świecie (Kraków: Zakład Wydawniczy „Nomos”, 2002), 92.

${ }_{52}$ Andrzej Nawrocki, „O projekcie Jean-Luc Nancy «Dekonstrukcji chrześcijaństwa»”, Kwartalnik Filozoficzny, 1 (2007): 40.

53 Jan Sochoń, Ponowoczesne losy religii (Warszawa: Oficyna Wydawniczo-Poligraficzna „Adam”, 2004), 142.

${ }^{54}$ Paulina Cembrzyńska, Wieża Babel. Nowoczesny projekt porzadkowania świata i jego 
I tak francuski filozof Jean-Luc Nancy (autor książki „Dekonstrukcja chrześcijaństwa") wykazuje, że chrześcijaństwo ukształtowało się w wyniku „sprzężenia ze sobą" takich dwóch elementów jak judaizm (przestrzeń działania „Innego”) i hellenizm (sfera logosu). W związku z tym chrześcijaństwo należy rozumieć jako grę owych dwóch składników. Pierwszy z nich ujawnia się w chrześcijaństwie działającym, drugi zaś w chrześcijaństwie refleksyjnym. Czy zatem chrześcijaństwo wnosi coś nowego? Nie można łatwo wykazać, że religia ta posiada jakieś oryginalne, świadczące o jej tożsamości, elementy. Gdyby jednak ten problem został rozwiązany, należy jeszcze zmierzyć się z zarzutem ,działania z pozycji siły i dominacji”"55. Chrześcijanie przecież, idąc za misyjnym nakazem Chrystusa, mają nauczać oraz chrzcić wszystkie narody w imię Trójcy Świętej (por. Mt 28, 19). Pojawia się tu zatem binarny układ podporządkowania. Wyznawcy Chrystusa, jako osoby roszczące sobie prawo do posiadania prawdy absolutnej, znajdowaliby się wyżej od osób, którym prawdy te dopiero są (lub będą) głoszone.

Pod wpływem dekonstrukcyjnej strategii myślenia Jean-Luc Nancy wypracował nowe rozumienie Wcielenia Syna Bożego oraz Jego Zmartwychwstania. Wcielenie byłoby rozpłynięciem się Boga w świecie. Natomiast zmartwychwstałe ciało Chrystusa to „ciało martwe, choć żywe”, takie ciało, „poprzez które zasada tożsamości i identyczności została przerwana” ${ }^{56}$. Wydaje się, iż zastosowaniem dekonstrukcyjnego sposobu myślenia jest chrześcijaństwo dialogiczne. „Dialog” nie jest tu jednak rozumiany jako proces polegający na wspólnym poszukiwaniu logosu, czyli obiektywnej, niezmiennej prawdy, niepodlegającej społecznym modyfikacjom. Tego typu dialogi (elenktyczno-majeutyczne) prowadził Sokrates ${ }^{57}$. Chrześcijaństwo dialogiczne jest niemetafizyczną formą tej religii odpowiadającą na potrzeby niemetafizycznej kultury ponowoczesnej. Osoby zaangażowane w tego typu dialog chrześcijański nie poszukują prawdy obiektywnej. Teoretycznym założeniem tej praktyki jest bowiem teza, iż ,chrześcijaństwo dialogiczne rezygnuje z roszczenia prawa do posiadania prawdy absolutnej, ak-

dekonstrukcja (Kraków: Towarzystwo Autorów i Wydawców Prac Naukowych Universitas, 2012), 63.

55 Nawrocki, „O projekcie”, 38-40.

${ }^{56}$ Błażej Baszczak, „Cielesność i dekonstrukcja chrześcijaństwa: Jean-Luc Nancy a Jacques Derrida”, Logos i Ethos 1 (2014): 29, 32-33.

57 Irena Krońska, Sokrates (Warszawa: Wiedza Powszechna, 1989), 72-76. 
centując otwartość prawdy na ostateczne spełnienie”58. Na pytanie, „czym jest chrześcijaństwo?”, chrześcijanin powinien zatem odpowiedzieć „,nie tak, nie tak" 59 .

Dekonstrukcyjny sposób myślenia zagraża katolickiej teorii i praktyce życia religijnego, ponieważ „chrześcijaństwo od samego początku rozumiało siebie jako religię Logosu, [czyli] religię według rozumu"60. Osłabienie rozumu czyli logosu oznacza zatem osłabienie, a nawet zanik, życia chrześcijańskiego (życia wiary). Tym, co stanowi „siłę żywiącą"1 rozumu (nie tylko chrześcijańskiego), jest filozofia. Poszukując rozumienia wiary, sięgano zawsze po argumenty filozoficzne (najpierw pochodzące $z$ klasycznej filozofii greckiej), które wykorzystał na przykład św. Tomasz z Akwinu do finezyjnego, a zarazem gruntownego wyjaśnienia prawd objawionych. Taką spekulację filozoficzna, powstającą w żywotnym związku z wiarą, nazwano filozofią chrześcijańską̨ ${ }^{62}$ Posługiwano się też argumentami zaczerpniętymi z augustianizmu, kantyzmu czy heglizmu. Należy pamiętać, iż również Marcin Luter oraz Karl Barth nie odeszli od myślenia i dziedzictwa filozoficznego. Dlatego „historia ewangelickiej teologii jest nie mniej ukształtowana przez wymianę z filozofią niż historia teologii katolickiej" ${ }^{63}$. A zatem filozoficzne sposoby rozumienia rzeczywistości to swoisty fundament przypominający „,zabytkowe metro, które cały czas działa i rozwozi mieszkańców naszej cywilizacji wedle własnego planu i rozkładu" ${ }^{4}$.

Związek religii i teologii z filozofią jest tak głęboki, iż na pewnym etapie historii utożsamiono chrześcijan z filozofami, określając prawdy wiary chrześcijańskiej mianem prawdziwej filozofii. Ścisła współpraca pomiędzy filozofią a teologią na ogół nie jest kwestionowana. $Z$ jednym tylko wyjątkiem - jeżeli odrzuca się filozofię, to nie filozofię w ogóle, lecz metafizykę w wersji Platona i Arystotelesa. Negując myślenie metafizyczne, otwiera się jednocześnie drzwi dla filozofii historycznej ${ }^{65}$. I tak, w czasach nam współczesnych preferowane są raczej filozofia hermeneutyczna, egzystencjalizm

58 Marek Szulakiewicz, „Od chrześcijaństwa metafizycznego do dialogicznego”, Więź 3 (2006): 44, 42-45.

59 Tamże, 44.

${ }^{60}$ Ratzinger, Europa, 65, 67.

${ }^{61}$ Jacek Breczko, „Między Atenami a Jerozolimą - cywilizacyjny termostat”, w: Breczko, Cywilizacja, 16.

62 Jan Paweł II, Fides, 76.

${ }_{63}$ Ratzinger, Prawda, 20.

${ }^{64}$ Breczko, „Między Atenami”, 16.

${ }^{65}$ Ratzinger, Prawda, 13, 21. 
i w końcu dekonstrukcja, która stanowi najnowszą wersję (strategię) negacji metafizyki. Jednak bez metafizyki ,wiara się wyczerpuje [...]. Rozwija się psychologia grobu, która stopniowo zamienia chrześcijan w muzealne mumie" ${ }^{66}$. Brak metafizyki powoduje, iż współcześni kapłani to „sfrustrowani stróże staroświeckiej doktryny, która nikomu nie jest już potrzebna"67.

\section{Dekonstrukcja jako wyzwanie dla pedagogiki religii}

Dla rozwoju życia religijnego (życia wiary) bardziej korzystny będzie zatem metafizyczny realizm, w którym centralne miejsce zajmują byty istniejące nie zaś byty możliwe. Pojawia się tu zatem kolejna perspektywa metafizyczna. Tylko bowiem z tej perspektywy można „zobaczyć” Boga jako Samoistne Istnienie, nie zaś teoretyczną fikcję. Istnienie jest bowiem najdoskonalszym elementem bytu. Dzięki niemu dana rzecz jest czymś realnym, a nie jedynie snem lub marzeniem. Wymiernym efektem metafizycznej refleksji jest też mądrość naturalna - wiedza o przyczynach rzeczywistości oraz mądrość nadprzyrodzona - znajomość początku i celu rzeczywistości, który w języku religijnym nazywany jest Bogiem. Wiedza i mądrość to dobra nie tylko intelektualne. Wiedza i mądrość chronią więź z Bogiem, czyli relację wiary, nadziei i miłości poddawaną swoistej próbie na etapie czynnych i biernych oczyszczeń pojawiających się w trakcie rozwoju życia religijnego. Myślenie metafizyczne stanowi wsparcie dla poprawnego rozumienia Boga jako początku i celu rzeczywistości ${ }^{68}$. „Siłą żywiącą” jest tu zatem ów realizm oraz swoiste posłuszeństwo intelektu rzeczywistości, a nie odwrotnie, jak sądził Immanuel Kant - autor teorii pojęć transcendentalnych, wyjaśniający, iż to dzięki nim „podmiot kształtuje przedmiot” ${ }^{69}$.

Filozofia jest więc pożyteczna dla teorii i praktyki życia religijnego $\mathrm{z}$ trzech powodów. Po pierwsze, brak filozoficznej formacji, zarówno u teologów, jak i u duszpasterzy oraz wiernych, oznacza niezdolność do formułowania argumentów odpierających zarzuty stawiane wobec prawd wiary. Stan

${ }^{66}$ Franciszek, Adhortacja apostolska Evangelii gaudium, 83, http://www.niedziela.pl/ /download/adhortacja_evangelii_gaudium.pdf

${ }^{67}$ Wiesław Śmigiel, „Nowa ewangelizacja wyzwaniem dla Kościoła”, Roczniki Teologiczne 6 (2014): 51.

${ }^{68}$ Gogacz, Podstawy, 49-66.

${ }^{69}$ Leszek Kołakowski, O co nas pytaja wielcy filozofowie, seria III (Kraków: Wydawnictwo Znak, 2006), 11-12. 
ten, jak dodaje Mieczysław A. Krapiec, można porównać do sytuacji osób chorych, zarażonych wirusem hiv/AIDS ${ }^{70}$. Bez wsparcia ze strony filozofii nie zostaną również wyjaśnione zagadnienia stworzenia świata, wcielenia i tożsamości Chrystusa oraz relacje w łonie Trójcy Świętej. Niejasne pozostaną problemy etyczne (sumienie, wolność, odpowiedzialność) ${ }^{71}$. Po drugie, bez myślowego wyobrażenia o realnym Bogu Stwórcy nawiązującym realne relacje osobowe, wiara pozostanie jakby „zawieszona w powietrzu”, pozbawiona swoistego punktu zaczepienia, jakim jest zakorzenienie w rozumie. Myślową bazę stanowi metafizyka realistyczna. Jej brak to intelektualna pustka $^{72}$. Wraz z nią „upadnie też sama myśl o Bogu”. Wiara będzie rozumiana jako czysty paradoks ${ }^{73}$. Należy przy tym pamiętać, iż na „pogrzebie” realnego Boga posypie się z nieba deszcz innych bogów (Kołakowski). Kult Boga żywego zostanie zastąpiony kultem sztuki, nauki, narodu i ludzkości ${ }^{74}$. $\mathrm{Z}$ genotypicznej religijności rozwinie się wiele jej fenotypicznych wyrazów w postaci różnych koncepcji bóstw oraz sposobów ich kultywowania. Człowiek jest bowiem z natury religijny (homo religiosus), natomiast z łaski wierzacy w Chrystusa (homo novus). Łaski wiary nie da się przekazać genetycznie, tak jak religijności, która jest niejako wrodzona ${ }^{75}$. Po trzecie, przyjmując tezę głoszącą niezbywalność filozoficznej refleksji w życiu religijnym człowieka, należy zastanowić się nad jakością owej filozoficznej refleksji. Najpierw zaś nad wyborem filozoficznego języka, w którym formułowane są owe przemyślenia. I tak, posługując się językiem idealizmu opowiemy o Bogu, który jest tylko treścią ludzkiej świadomości. Taką ideę Boga będzie można dowolne kształtować ${ }^{76}$. Od pojęcia Boga zależy z kolei intensywność przeżyć religijnych. Praktyka jest bowiem zawsze na miarę teorii. Dlatego też można przypuszczać, za Étienne Gilsonem, że przyczyną braku wiary w Boga jest brak właściwego pojęcia Boga ${ }^{77}$. O Bogu istniejącym poza ludz-

70 Porzucić świat absurdów. Z Mieczysławem A. Krapcem rozmawia ks. J. Sochoń (Lublin: Polskie Towarzystwo Tomasza z Akwinu, 2002), 125.

71 Jan Paweł II, Fides, 66-69.

72 Ratzinger, Wiara, 40-41, 43.

73 Ratzinger, Prawda, 20-21.

${ }^{74}$ Jacek Breczko, „Dowody na istnienie Boga «nie wprost» a koniec nowożytności”, w: Breczko, Dwa tysiace, 80.

${ }^{75}$ Antoni J. Nowak, Homo religiosus. Studium porównawczo-krytyczne (Lublin: Wydawnictwo KUL, 2003), 144-146.

76 Jan Paweł II, Pamięć i tożsamość. Rozmowy na przełomie tysiqcleci (Warszawa: De Agostini Polska, 2007), 15-16.

77 Porzucić świat absurdów, 125. 
ką świadomością można zaś mówić językiem metafizycznym. Metafizyk nie zajmuje się bowiem tym, co pomyślane, lecz tym, co realne.

Pierwszorzędnym działaniem wychowawczym (w ramach pedagogiki religijnej) będzie zatem wychowanie integralne $\mathrm{e}^{78}, \mathrm{w}$ tym usprawnienie intelektu w nabywaniu wiedzy i mądrości. Najpierw zaś ochrona przed szkodliwym wpływem filozoficznych sposobów myślenia, zwłaszcza zaś przed dekonstrukcyjnym sposobem myślenia. W tym sensie można mówić, że dekonstrukcja (będąca zagrożeniem dla ludzkiego rozumu) stanowi wyzwanie dla pedagogiki religii. Życiu religijnemu bowiem bardziej służy wzmacnianie logosu (poprzez nabywanie wiedzy i mądrości), a nie jego dekonstrukcja (poprzez wprowadzanie w „mgławicę niepewności”). Łaska bowiem buduje na naturze. Zresztą, czy zdekonstruowany rozum będzie zdolny wypełnić przykazanie miłości, zgodnie z którym należy kochać Boga, nie tylko całym sercem, lecz również umysłem? Jeżeli zaś życie wieczne ma polegać na poznawaniu Boga (por. J 17, 3), to jak temu zadaniu sprosta umysł zdekonstruowany? Należy tu również pamiętać, iż logika, czyli sens, nie tylko zabezpiecza życie wieczne, lecz również chroni życie doczesne, czego przykładem są takie oto zdania, które różnią się pomiędzy sobą logicznym akcentem: „Przebaczyć nie można. Ukarać” oraz „Przebaczyć. Nie można ukarać" 79 .

\section{Zakończenie}

Podsumowując różnorodne wątki tej refleksji, wyobraźmy sobie termostat, czyli urządzenie, które utrzymuje stałą (wyznaczoną) temperaturę jakiegoś pomieszczenia. Wyobraźmy sobie również „termostat kulturowy (cywilizacyjny)". Ten typ urządzenia wskazywałby z kolei na temperaturę duchową (intelektualną) poszczególnych osób lub społeczeństw - klimat relatywizmu („niż ateński”) lub klimat poszukiwania pewników („wyż jerozolimski"). Przypuszcza się, iż kiedy kulturowy termostat osiagnie swoje apogeum (czyli skraj), to wtedy nastapi odwrócenie jego wskazówek. Jeśli zatem owym apogeum będzie relatywizm (obecnie dekonstrukcja), to wskazówki owego urządzenia zaczną przesuwać się w kierunku epoki pewni-

${ }^{78}$ Wojciech Cichosz, Pedagogia wiary we wspótczesnej szkole katolickiej (Warszawa: Wydawnictwo Typo 2, 2010), 100-130.

79 Stanisław Prygoń, Interpretacja. Mówię, czytam, wygłaszam (Warszawa: Książka i Wiedza, 2007), 28. 
ków ${ }^{80}$. Jednak wbrew takim przewidywaniom, można sądzić, iż wskazówki tego miernika na nic już nie wskazuja, ponieważ wypadły ze skali ${ }^{81}$. W tym przypadku ruch jest wszystkim, cel niczym ${ }^{82}$. Dekonstrukcyjny sposób myślenia, kształtujący mentalność człowieka XXI wieku, to przecież strategia pozbawiona określonego początku i wyznaczonego końca ${ }^{83}$.

Antyteleologiczny program dekonstrukcji jest egzemplifikacją przekonania o tym, że nie można poznać prawdy obiektywnej ${ }^{84}$. Jednak osoby akceptujące ową tezę przeczą samym sobie, ponieważ głoszenie prawdy, że nie można poznać prawdy, już jest przecież jakąś prawdą. Byłoby to zatem przypisywanie sobie wiedzy „o czymś, czego, jak sami twierdzą, poznać nie można" $"$.

\section{Deconstruction of the Logos as a Threat to Religious Life (Summary)}

Christianity understands itself as a religion of logos, that is, a religion in accord with reason. Therefore, a weakening of reason, which is the logos, indicates a weakening, and even the degeneration of Christian life. In order to understand the truths of faith, philosophical arguments have been used. Deconstruction is a contemporary style of philosophical thought, which prevents understanding, for it serves not in the formulation of reasonable answers nor in demonstrating a lack of sense. Therefore, deconstruction demolishes the logocentric mode of thought that is "meaning," "understanding" and "certainty." Hence, it constitutes a threat to a life of faith that seeks understanding (fides quaerens intellectum).

Key words: logos; deconstruction; faith; metaphysics; religious education.

${ }^{80}$ Breczko, „Między Atenami”, 27-28.

${ }^{81}$ Por. Chip Morningstar, How To Deconstruct Almost Anything My Postmodern Adventure, www.wolnewyrazy.pl/.../how-top-deconstruct-almost-antything/.

82 Breczko, „Nowożytność,” 66.

83 Jacques Derrida, O gramatologii (Warszawa: „KR”, 1999), 104-105.

${ }^{84}$ Richard Rorty, Objectivity, relativism and truth (Cambridge: Cambridge University Press, 1991), 160-162.

${ }^{85}$ Richard Rorty, Przygodność, ironia, solidarność (Warszawa: Wydawnictwo W.A.B., 1996), 25. 


\section{Dekonstrukcja logosu jako zagrożenie życia religijnego (Streszczenie)}

Chrześcijaństwo rozumie siebie jako religię logosu, czyli religię według rozumu. Osłabienie rozumu, czyli logosu, oznacza zatem osłabienie, a nawet zanik, życia chrześcijańskiego. W celu zrozumienia prawd wiary posługiwano się argumentacją filozoficzną. Współczesnym stylem filozoficznego myślenia jest dekonstrukcja. Jednak dekonstrukcja uniemożliwia rozumienie. Nie służy bowiem do sformułowania sensownych odpowiedzi czy wykazania braku sensu, lecz uwalnia od sensu. Dekonstrukcja burzy zatem logocentryczny sposób myślenia, czyli „,znaczenie”, „rozumienie”, „pewność”. Dlatego stanowi zagrożenie dla życia wiary poszukującej zrozumienia (fides quaerens intellectum).

Slowa kluczowe: logos; dekonstrukcja; wiara; metafizyka; pedagogika religijna.

\section{Bibliografia}

Augustyn. „De praedestinatione sanctorum”. W: Patrologia Latina I-CCXVII (I-IV Indices), red. J. P. Migne. Paris 1878-1890.

Banasiak, Bogdan. Filozofia „końca filozofii”. Dekonstrukcja Jacquesa Derridy. Warszawa: Spacja, 1997.

Baszczak, Błażej. „Cielesność i dekonstrukcja chrześcijaństwa: Jean-Luc Nancy a Jacques Derrida”. Logos i Ethos 1 (2014), 21-50.

Benedykt XVI. „Wiara, rozum i uniwersytet - wspomnienia i refleksje”. L'Osservatore Romano 11 (2006): 25-27.

Bennington, Geoffrey. „Deconstruction is not what you think”. W: Deconstruction:

Omnibus Volume, red. A. Papadakis, C. Cooke, A. Benjamin. London: Academy Editions, 1989.

Borowska, Ewa. Problem metafizyki. Ewolucja metafizyki europejskiej w interpretacji późnego Heideggera. Warszawa: Wydawnictwo Naukowe Scholar, 2008. Breczko, Jacek. „Dwa tysiące sześćsetletni poród: zmierzch czy świt filozofii?”. Sofia 7 (2007): 345-352.

Breczko, Jacek. Cywilizacja na zakręcie. Szkice z historii filozofii i z filozofii historii. Lublin: Norbertinum, 2014.

Breczko, Jacek. Dwa tysiqce sześćsetletni poród. Wstęp do filozofii. Białystok: Wyższa Szkoła Administracji Publicznej im. Stanisława Staszica, 2007. 
Burzyńska, Anna. Dekonstrukcja i interpretacja. Kraków: Towarzystwo Autorów i Wydawców Prac Naukowych Universitas, 2001.

Cembrzyńska, Paulina. Wieża Babel. Nowoczesny projekt porzqdkowania świata i jego dekonstrukcja. Kraków: Towarzystwo Autorów i Wydawców Prac Naukowych Universitas, 2012.

Cichosz, Wojciech. Pedagogia wiary we wspótczesnej szkole katolickiej. Warszawa: Wydawnictwo Typo 2, 2010.

Cichosz, Wojciech. Wychowanie chrześcijańskie wobec postmodernistycznej prowokacji. Gdańsk: Zakłady Graficzne im. KEN, 2001.

Derrida, Jacques. „List do japońskiego przyjaciela”. W: Efekt inskrypcji. Jacques Derrida i literatura, red. Michał P. Markowski. Bydgoszcz: Studio $\Phi$ : „Homini", 1997.

Derrida, Jacques. O gramatologii. Warszawa: „KR”, 1999.

Dummet Michael. Logiczna podstawa metafizyki. Natura i przyszłość filozofii. Warszawa: Państwowe Wydawnictwo Naukowe, 1998.

Ferszt-Piłat, Katarzyna. „Zaufanie jako fundament bezpieczeństwa we współczesnym społeczeństwie”. Journal of Modern Science 3 (2012): 109-124.

Franciszek. Adhortacja apostolska Evangelii gaudium. http://www.niedziela.pl/download/adhortacja_evangelii_gaudium.pdf.

Furmanek, Waldemar. „Banalizacja urzeczywistniania wartości”. W: Wartości w pedagogice. Urzeczywistnianie wartości, red. Waldemar Furmanek, Agnieszka Długosz, 173-183. Rzeszów: Wydawnictwo Uniwersytetu Rzeszowskiego, 2015.

Gellner, Ernest. Postmodernizm, rozum i religia. Warszawa: Państwowy Instytut Wydawniczy,1997.

Gogacz, Mieczysław. Elementarz metafizyki. Warszawa: Oficyna Wydawnicza „Navo”, 2008.

Gogacz, Mieczysław. Podstawy wychowania. Niepokalanów: Wydawnictwo oo. Franciszkanów, 1993.

Jan Paweł II. Fides et ratio. Poznań: Pallottinum 1998.

Jan Paweł II. Pamięć i tożsamość. Rozmowy na przetomie tysiacleci. Warszawa: De Agostini Polska, 2007.

Kołakowski, Leszek. O co nas pytaja wielcy filozofowie. Seria III. Kraków: Wydawnictwo Znak, 2006.

Krońska, Irena. Sokrates. Warszawa: Wiedza Powszechna, 1989.

Łażewska, Dorota. „Derridiańska dekonstrukcja jako strategia odrzucania wartości prawdy w pedagogice". W: Wartości w pedagogice. Urzeczywistnianie wartości, red. Waldemar Furmanek, Agnieszka Długosz, 165-172. Rzeszów: Wydawnictwo Uniwersytetu Rzeszowskiego, 2015. 
Maksymiuk, Piotr. „Derridiański taniec”. Preteksty 4 (2007): 95-114.

Marquard, Odo. Rozstanie z filozofia pierwszych zasad: studia filozoficzne. Warszawa: Oficyna Wydawnicza, 1994.

Mazur, Tomasz. Kapryśni bogowie Sokratesa. Człowiek i świat wartości w tradycji filozofii zachodniej. Kęty: Wydawnictwo Marek Derewiecki, 2008.

Mizielińska, Joanna. (De)Konstrukcje kobiecości. Podmiot feminizmu a problem wykluczenia. Gdańsk: Słowo/Obraz/ Terytoria, 2004.

Morningstar, Chip. How To Deconstruct Almost Anything My Postmodern Adventure. www.wolnewyrazy.p1/.../how-top-deconstruct-almost-antything/.

Nawrocki, Andrzej. „O projekcie Jean-Luc Nancy «Dekonstrukcji chrześcijaństwa»". Kwartalnik Filozoficzny 1 (2007): 37-59.

Nowak, Antoni J. Homo religiosus. Studium porównawczo-krytyczne. Lublin: Wydawnictwo KUL, 2003.

Porzucić świat absurdów. Z Mieczysławem A. Krapcem rozmawia ks. J. Sochoń. Lublin: Polskie Towarzystwo Tomasza z Akwinu, 2002.

Prygoń, Stanisław. Interpretacja. Mówię, czytam, wygłaszam. Warszawa: Książka i Wiedza, 2007.

Ratzinger, Joseph. Europa Benedykta w kryzysie kultur. Częstochowa: Edycja św. Pawła, 2005.

Ratzinger, Joseph. Patrzqc na Chrystusa. Ćwiczenia w wierze, nadziei, mitości. Warszawa: Katolicka Agencja Wydawnicza „MAG”, 1991.

Ratzinger, Joseph. Prawda w teologii. Kraków: Wydawnictwo M, 2005.

Ratzinger, Joseph. Wiara i przyszłość. Kraków: Wydawnictwo Salwator, 2007.

Reale, Giovanni. Historia filozofii starożytnej. T. I. Od poczatków do Sokratesa. Lublin: Redakcja Wydawnictw KUL, 1994.

Reale, Giovanni. Historia filozofii starożytnej. T. II. Platon i Arystoteles. Lublin: Redakcja Wydawnictw KUL, 1997.

Rorty, Richard. Objectivity, relativism and truth. Cambridge: Cambridge University Press, 1991.

Rorty, Richard. Przygodność, ironia, solidarność. Warszawa: Wydawnictwo W.A.B., 1996.

Scupoli, Wawrzyniec. Walka duchowa. Poznań: Klub Książki Katolickiej, 2002.

Slany, Krystyna. Alternatywne formy życia malżeńsko-rodzinnego w ponowoczesnym świecie. Kraków: Zakład Wydawniczy „Nomos”, 2002.

Sochoń, Jan. Ponowoczesne losy religii. Warszawa: Oficyna Wydawniczo-Poligraficzna „Adam”, 2004.

Swieżawski, Stefan. Dobro i tajemnica. Warszawa: Biblioteka „Więzi”, 1995.

Szulakiewicz, Marek. „Od chrześcijaństwa metafizycznego do dialogicznego”. Więź 3 (2006), 34-45. 
Śmigiel, Wiesław. „Nowa ewangelizacja wyzwaniem dla Kościoła”. Roczniki Teologiczne 6 (2014): 41-55.

Welsch, Wolfgang. „Rozum i przejścia. O rozumie transwersalnym”. W: Rozumność i racjonalność, red. Tadeusz Buksiński, 91-110. Poznań: Wydawnictwo Naukowe Instytutu Filozofii UAM, 1997.

Welsch, Wolfgang. Nasza postmodernistyczna moderna. Warszawa: Oficyna Wydawnicza, 1998.

Zdybicka, Zofia J. Człowiek i religia. Zarys filozofii religii. Lublin: Wydawnictwo Towarzystwa Naukowego KUL, 1993.

Zięba, Waldemar. Dekonstrukcja metafizyki. Powstanie (J. Derrida) - Rozkwit Niespetnienie (R. Rorty). Rzeszów: Wydawnictwo Uniwersytetu Rzeszowskiego, 2009.

Żardecka-Nowak, Magdalena. Wspólnota i ironia. Richard Rorty i jego wizja spoteczeństwa liberalnego. Lublin: Wydawnictwo KUL, 2003. 
